J. Amer. Soc. Hort. ScI. 127(4):623-627. 2002.

\title{
Molecular Markers Used to Verify Interspecific Hybridization between Hemlock (Tsuga) Species
}

\author{
Margaret R. Pooler and Louise G.H. Riedel \\ U.S. Department of Agriculture, Agricultural Research Service, U.S. National Arboretum, 3501 New \\ York Ave., NE, Washington, DC 20002 \\ S.E. Bentz and A.M. Townsend \\ U.S. Department of Agriculture, Agricultural Research Service, U.S. National Arboretum, 11601 Old \\ Pond Dr., Glenn Dale, MD 20769
}

\begin{abstract}
AdDITIONAL INDEX wORDS. AFLP, DNA fingerprinting, ITS, plant breeding, RAPD, SCAR, SSR
Abstract. Controlled pollinations were made between five hemlock (Tsuga) species from eastern North America and Asia, resulting in over 5700 germinating seedlings. A subset of putative hybrid seedlings from each cross was tested for authenticity by various DNA marker systems. The most reliable and useful system for verifying hybrids was amplified fragment-length polymorphism (AFLP) markers. Hybridizations between the eastern North American species, $T$. canadensis [L.] Carriere and T. caroliniana Engelm., and the Asian species, T. chinensis (Franch.) E. Pritz., were used as a model to test the inheritance, reliability, and ease of use of these markers. Using AFLP markers, we were able to verify 58 hybrids between $T$. caroliniana and $T$. chinensis, one hybrid between $T$. caroliniana and $T$. canadensis, but could find no definitive hybrids between $T$. canadensis and $T$. chinensis. Results using other marker systems, including RAPD, SCAR, ITS, and SSR, are also presented.
\end{abstract}

The canadian hemlock, Tsuga canadensis [L.] Carriere, is an important species in both forest and landscape settings. Its native range extends from Quebec and Prince Edward Island to Alabama, and west to Minnesota (Taylor, 1993). It is an important component of forest ecosystems as a source of food and shelter for wildlife (Quimby, 1996) and as a long-lived late successional climax species. Additionally, it has value as a timber crop and is an important nursery crop, with over 200 named selections (Swartley, 1984). The carolina hemlock, T. caroliniana Engelm., is found on rocky montane slopes in the southern range of the canadian hemlock, and also plays an important role in the health of forest ecosystems.

The two eastern North American species, T. canadensis and $T$. caroliniana, have suffered severe damage and mortality following infestation from the hemlock woolly adelgid Adelges tsugae (Annand) (McClure, 1987; Souto and Shields, 2000). The adelgid, an introduced pest from Asia, feeds on the xylem fluid of young twigs, and can kill a tree within several years of infestation (McClure, 1992; McClure et al., 1996; Young et al., 1995). This pest is now established in 11 eastern states from Massachusetts to North Carolina (McClure, 1987; McClure et al., 1996), occupying about half the natural range of $T$. canadensis.

Biological or chemical control of the adelgid may be possible, but is difficult (Gouli et al., 1997; McClure, 1995; Montgomery, 1999). Research at the U.S. National Arboretum site at Glenn Dale, Md., has focused on genetic resistance to the wooly adelgid by crossing the more susceptible native eastern North American hemlock species with the more resistant Asian species, $T$.

Received for publication 17 Jan. 2002 . Accepted for publication 16 Apr. 2002. Mention of a trademark, proprietary product, or vendor does not constitute a guarantee or warranty of the product by the U.S. Department of Agriculture and does not imply an endorsement of these products over others not mentioned. This research was funded in part by USDA Forest Service Forest Health Technology Enterprise Team Agreement 11-2442-97-05, and by the International Society of Arboriculture Research Trust. We thank Clay Deming and Rosemary Bordley for technical support with RAPD and SCAR work, Mike Reinsel for technical support in running AFLP samples on the ABI310, and Tom Abell for support of plant breeding activities and daily plant maintenance. diversifolia (Maxim.), T. chinensis (Franch.) E. Pritz, and T. seiboldii Carriere. We recently reported the results of six years of controlled pollinations within Tsuga (Bentz et al., 2002), and concluded that hybridization between $T$. canadensis and the Asian species is difficult to achieve, although we did obtain hybrids among the Asian species and between some of the Asian species and T. caroliniana. Because morphological characters are inadequate to distinguish between hybrid and nonhybird Tsuga seedlings, a molecular marker system was needed to verify hybrids. Here we report the use of amplified fragment-length polymorphisms (AFLPs) to verify some of the Tsuga interspecific hybrids. We also report the limited results obtained from other marker techniques, including randomly amplified polymorphic DNA (RAPD) markers, sequence tagged site (STS) markers, sequence characterized amplified regions (SCARs), internal transcribed spacer (ITS) regions, and simple sequence repeat (SSR) markers.

\section{Materials and Methods}

Pollination AND SEed Collection. Methods are as described previously (Bentz et al., 2002). Briefly, controlled pollinations between hemlock species were carried out from 1991-95 and 1997-98 using the species listed in Table 1, as well as the Asian species, T. seiboldii and T. diversifolia. Trees were located in Washington, D.C.; Glenn Dale, Md.; Bethesda, Md.; Boyce, Va.; and Philadelphia, Pa. Interspecific, intraspecific, and self pollinations were made. Starting in 1994, branches were emasculated by removing male cones from branches, following our observation that selfed trees in the 1991-93 crosses produced seed and viable offspring. Resulting seedling plants were grown in greenhouses or polyhouses.

DNA EXTRACTION. Fresh, newly expanding leaves were collected, freeze-dried, and stored at $-70{ }^{\circ} \mathrm{C}$ until used. For each sample, five to six leaves were placed in a lysing matrix (Bio101, Vista, Calif.) with $500 \mu \mathrm{L}$ CTAB buffer and processed in a FastPrep FP120 machine (Bio101) on speed 4 for 12 s. The resulting homogenate was incubated at $65{ }^{\circ} \mathrm{C}$ for $15 \mathrm{~min}$ then 
Table 1. Summary of controlled hybridizations between the eastern North American hemlock species and T. chinensis and resulting verified interspecific hybrid progeny, and AFLP selective primer extension used to test hybrids. For summary of results of all Tsuga hybridizations, see Bentz et al. (2002).

\begin{tabular}{|c|c|c|c|c|c|}
\hline $\begin{array}{l}\text { Female } \\
\text { parent }\end{array}$ & $\begin{array}{l}\text { Male } \\
\text { parent }\end{array}$ & $\begin{array}{c}\text { No. of } \\
\text { seedlings } \\
\text { germinated }\end{array}$ & $\begin{array}{l}\text { No. of } \\
\text { crosses } \\
\text { examined }\end{array}$ & $\begin{array}{l}\text { No. verified as } \\
\text { hybrids/total no. } \\
\text { seedlings tested }\end{array}$ & $\begin{array}{l}\text { Avg. no. of transmitted paternal AFLP markers/total paternal AFLP } \\
\text { markers used (no. progeny in population) and AFLP selective primer } \\
\text { extensions (EcoRI/MseI) used for that cross }\end{array}$ \\
\hline \multirow[t]{3}{*}{ T. canadensis $\mathrm{X}$} & $\begin{array}{l}\text { T. canadensis } \\
\text { (including selfs) }\end{array}$ & 2545 & --- & --- & \\
\hline & T. caroliniana & 447 & 1 & $0 / 6$ & 0/5(6)-AG/TC, CT/TC, GG/AT \\
\hline & T. chinensis & 543 & 4 & $0 / 36$ & $\begin{array}{l}\text { 1/10(7); 1.2/10(6); 2/8(2)-AC/TC, CG/TG, GC/TG, GG/TT } \\
\text { 0/5(21)-CG/AC, CG/TA, GC/TG }\end{array}$ \\
\hline \multirow{2}{*}{ T. caroliniana $\mathrm{x}$} & T. canadensis & 60 & 1 & $1 / 10$ & 1.0/5(10)-AG/TC, GC/AC, GG/TA \\
\hline & T. chinensis & 186 & 3 & $43 / 49$ & $\begin{array}{l}\text { 2/5(7); 4.2/5(17)-CG/TG, GC/AC, GC/TG } \\
\text { 3.9/4(25)-CG/TA, GC/AC, GC/TG }\end{array}$ \\
\hline \multirow[t]{2}{*}{ T. chinensis $\mathrm{x}$} & T. chinensis (self) & 7 & --- & --- & \\
\hline & T. canadensis & 7 & 3 & $0 / 4$ & 2/11(2); 2/11(1); 1.5/9(1)-AC/AA, AC/TC, CC/AG, GC/AC \\
\hline
\end{tabular}

extracted with $500 \mu \mathrm{L}$ of 24 chloroform : 1 isoamyl alcohol. The DNA from this crude first extraction was then further purified using the QIAamp tissue kit (Qiagen, Inc., Chatsworth, Calif.). DNA purity and quantity were estimated by visual comparison with known standards on a $1 \%$ agarose gel.

RAPD-PCR.PCR was performed in $25-\mu \mathrm{L}$ volumes containing PCR buffer (20 mм NaCl, $50 \mathrm{~mm}$ Tris $\mathrm{pH}$ 9.0, $1 \%$ Triton X-100 [Barry et al., 1991]), $3 \mathrm{~mm} \mathrm{MgCl} 2,200 \mu \mathrm{M}$ dNTP, $0.2 \mu \mathrm{M}$ primer (primers with $70 \%$ to $90 \% \mathrm{G}+\mathrm{C}$ content were selected from UBC sets 1 and 4; UBC Nucleic Acid-Protein Service Unit, Vancouver, B.C., Canada), 0.25 U of Taq DNA polymerase (Promega Corp., Madison, Wis.), and $10 \mathrm{ng}$ DNA template. DNA amplification was carried out in a GeneAmp PCR System 2400 (Applied Biosystems, Foster City, Calif.) programmed for 45 cycles of 30 $\mathrm{s}$ at $95{ }^{\circ} \mathrm{C} ; 30 \mathrm{~s}$ at $48{ }^{\circ} \mathrm{C}$ and $45 \mathrm{~s}$ at $72{ }^{\circ} \mathrm{C}$. RAPD reactions were analyzed on $1.4 \%$ agarose TBE gels stained with ethidium bromide. Gels were visualized and documented using an AlphaImager 2000 (Alpha Innotech Corp., Alameda, Calif.). All reactions were repeated at least once to insure reproducibility of scored amplification products.

STS AND SCAR ANALYSIS. STS primer pairs from black spruce, Picea mariana (Mill.) (SB12, SB31, and SB32) (Perry and Bousquet, 1998a) were synthesized by Ransom Hill Bioscience (Ramona, Calif.). Sequence characterized amplified region (SCAR) (Paran and Michelmore, 1993) primers were derived by excising species-specific RAPD bands from agarose gels and purifying with the GeneClean kit (Bio101). Purified DNA was cloned into the TA cloning vector (Invitrogen, San Diego, Calif.) and the plasmid was introduced into competent $E$. coli according to the manufacturer's instructions. Plasmid was isolated from $E$. coli using Qiagen plasmid DNA purification kits, and the inserts were partially sequenced from each end using the BigDye terminator cycle sequencing kit (Applied Biosystems) and analyzed on an ABI310 genetic analyzer (Applied Biosystems). Primers consisting of the original 10-nucleotide RAPD primer plus the next 8 to 12 sequenced nucleotides were synthesized by Ransom Hill Bioscience (Table 2). Amplification reactions were carried out in a T3 thermocycler (Biometra, Gottingen, Germany) using the PCR mixture described above for RAPD markers with $0.4 \mu \mathrm{M}$ each primer using an amplification profile of 35 cycles of $30 \mathrm{~s}$ at $94{ }^{\circ} \mathrm{C}, 45 \mathrm{~s}$ at the annealing temperature, and $45 \mathrm{~s}$ at $72^{\circ} \mathrm{C}$. Initial annealing temperatures were the same as the Tm supplied by the primer manufacturer, and were adjusted as necessary to achieve optimum specificity.

ITS ANALYSIS. The universal primer ITS5 (White et al., 1990) and hemlock primer ITS2a (Vining, 1999; Table 2) were used to amplify a $1440 \mathrm{bp}$ fragment, and the universal primers ITS4 and ITS3 (White et al., 1990) were used to amplify a $500 \mathrm{bp}$ fragment in all Tsuga species. The amplified products from T. chinensis and T. caroliniana were cloned, sequenced, and subjected to sequence comparison and restriction site analysis. GeneClean purified DNA from the amplified ITS5-ITS2a regions was subjected to restriction enzyme digestion using EcoRI or $B g l \mathrm{I}$ (Promega Corp.) according to the supplier's recommended procedures. Sequence differences were used to design two putative species-specific primers, Tcar425 and Tchin 300 to be used with ITS5 and ITS3, respectively (Table 2).

SSR ANALYSIS. SSR primer pairs BCThAC4 (formerly HS15), BCThAC5 (formerly HS17), BCThAC7 (formerly HS26) and BCThAC12b (formerly HW2LT1B11) from J. Carlson's laboratory at Pennsylvania State University (www.personal.psu.edu/ faculty/j/e/jec16/Micro- DNA05.htm) originally designed for $T$. heterophylla were used to amplify genomic DNA from all species following the methods on Carlson's web site. Products were analyzed initially on agarose gels to ascertain presence of a product before analysis on a sequencing gel using radiolabelled dNTPs.

AFLP ANALYSIS. AFLP electropherograms were generated for parents and progeny using protocols described by Vos et al. (1995) and Perkin- Elmer Corporation (1996), with slight modifications, to prepare samples for analysis on an ABI 310 genetic analyzer. DNA restriction and ligation were carried out sequentially instead of simultaneously, using $\approx 0.25 \mu \mathrm{g}$ of genomic DNA. Restriction was carried out at $37^{\circ} \mathrm{C}$ for $2 \mathrm{~h}$, and ligations were carried out at $20^{\circ} \mathrm{C}$ for $2 \mathrm{~h}$. Preselective reactions were carried out in $20-\mu \mathrm{L}$ volumes containing the buffer described above for RAPDs, plus $3 \mathrm{~mm} \mathrm{MgCl} 2,100 \mu \mathrm{M}$ dNTP, $0.125 \mu \mathrm{M}$ each preselective primer, $0.625 \mathrm{U}$ of Taq DNA polymerase, and $4 \mu \mathrm{L}$ diluted restriction/ligation reaction. Completed preselective reactions were diluted with $380 \mu \mathrm{L}$ molecular grade water and 3 $\mu \mathrm{L}$ were used as template for all selective reactions. Selective amplification reactions were carried out in $20-\mu \mathrm{L}$ volumes con- 
Table 2. Primer name, species specificity, annealing temperature, PCR product size, and sequence of SCAR primer pairs that were useful for discriminating between the accessions of Tsuga species used in this study.

\begin{tabular}{|c|c|c|c|c|c|}
\hline $\begin{array}{l}\text { Primer } \\
\text { name }\end{array}$ & Specificity & $\begin{array}{c}\text { Annealing } \\
\text { temp } \\
\left({ }^{\circ} \mathrm{C}\right)\end{array}$ & $\begin{array}{l}\text { Size } \\
\text { (bp) }\end{array}$ & Forward sequence $\left(5^{\prime}-3^{\prime}\right)$ & Reverse sequence (5'-3') \\
\hline $63 \mathrm{AB}$ & T. seiboldii & 68 & 400 & TTCCCCGCCCCCATCAAG & TTCCCCGCCCGATTTCTTTA \\
\hline $63 \mathrm{C}$ & T. canadensis & 68 & 1200 & TTCCCCGCCCGATCAAGAAAT & TTCCCCGCCCCAATGGAAAC \\
\hline $349 \mathrm{~K}$ & $\begin{array}{l}\text { T. seiboldii, } \\
\text { T. chinensis }\end{array}$ & 55 & 700 & GGAGCCCCCTTAGATCT & GGAGCCCCCTTTGCCTACGTTA \\
\hline $63 \mathrm{KL}$ & T. chinensis & 68 & 1350 & TTCCCCGCCCGAACATAAG & TTCCCCGCCCTGGCCCAA \\
\hline $84 \mathrm{AB}$ & $\begin{array}{l}\text { T. seiboldii, } \\
\text { T. diversifolia }\end{array}$ & 65 & 500 & GGGCGCGAGTATAGAACTTCC & GGGCGCGAGTGCAAGCAAGC \\
\hline $349 \mathrm{C}$ & T. canadensis & 64 & 450 & GGAGCCCCCTAGGGAAAAAC & GGAGCCCCCTGATATCTAGCGA \\
\hline $72 \mathrm{AB}$ & $\begin{array}{l}\text { T. seiboldii, } \\
\text { T. chinensis }\end{array}$ & 66 & 550 & GAGCACGGGACTGTCATTTAC & GAGCACGGGAGAAGGAGATT \\
\hline
\end{tabular}

taining the same reagents as for preselective amplification except that $0.25 \mu \mathrm{M} \mathrm{MseI} \mathrm{primer} \mathrm{and} 0.1 \mu \mathrm{M} E c o$ RI primers were used instead of preselective primers. The EcoRI selective primers had fluorescently labelled 5' ends and were purchased from the Applied Biosystems Custom Oligonucleotide Synthesis Service. Completed selective reactions were analyzed on an ABI310 with POP4 polymer. The sample was prepared by mixing $1 \mu \mathrm{L}$ of selective reaction, $0.3 \mu \mathrm{L}$ ROX size standard, and $9.7 \mu \mathrm{L}$ deionized formamide. Parent-unique markers were scored with Genotyper 2.5 software (Applied Biosystems). Selective reactions were repeated at least once for all samples.

ASSESSING SAMPLES FOR HYBRIDITY. DNA from the female parent, the putative male parent, and a minimum of 10 progeny, or all living progeny when fewer than 10, were analyzed. Analysis of a mixture of DNA from the two parents served as a control to ascertain possible interactions between genotypes. Additionally, analysis of DNA from a self- or open-pollinated seedling from the putative male parent was used as a control to ensure transmission of the markers. Chi-square goodness of fit values were estimated and compared to $\chi^{2}{ }_{0.05}=3.84$ for 1 degree of freedom. Values were calculated for male-specific markers using both a 1:0 expected transmission ratio (expected if the marker is homozygous in the male parent) and a 1:1 transmission ratio (expected if the marker is heterozygous in the male parent). Transmission to a progeny of at least $50 \%$ of the male-specific markers that had acceptable $\chi^{2}$ values was considered evidence that the plant was a hybrid.

\section{Results}

Analysis of hemlock parents and progeny using AFLP markers proved to be the most reliable and cost-effective method to differentiate among species and verify hybrid progeny. We screened 44 AFLP selective primer pairs, all of which produced amplification products (Fig. 1). The number of peaks scored ranged from 60 to 120 , with most of the useful peaks in the size range of 90 to $250 \mathrm{bp}$. For each cross, 4 to 11 peaks from 3 to 4 primer pairs were used to verify hybrids (Table 1). Despite the power and objectivity of computer-assisted AFLP band calling, we analyzed each peak called by the Genotyper software visually to ensure its reliability. A large number of peaks that were originally scored by the computer as polymorphic were rejected after our review. In most cases, the peak could be seen in both parents, but fell below the baseline for scoring in one parent, and was therefore not scored by the software. We relied only on peaks that were expressed strongly in the male parent and were not visible in the female parent. Our strict criteria for selection of peaks resulted in confidence in our verification of hybrids, but probably also resulted in the dismissal of some peaks that could have been informative.

Most markers used to verify hybrids followed predicted Mendelian segregation ratios. For example, all four of the markers used to analyze the twenty-five progeny of one of the T. caroliniana x $T$. chinensis crosses appeared to be homozygous in the $T$. chinensis male parent, with $\chi^{2}$ values of 0 to 0.16 (for a 1:0 expected segregation ratio) for each marker. In a different $T$. caroliniana $\times T$. chinensis cross with twenty-four progeny, three of the markers appeared to be homozygous in the $T$. chinensis male parent with $\chi^{2}$ values of 0.17 to 1.5 and two of the markers appeared to be heterozygous in the $T$. chinensis male parent with $\chi^{2}$ values of 1.6 or 0.66 . Five of the six markers identified in the reciprocal cross, $T$. chinensis $\times T$. caroliniana, followed expected segregation ratios. The one marker that did not fit the expected 1:0 or 1:1 ratio was present in only one of the sixteen progeny and was therefore not used for hybrid identification.

Although AFLP markers ultimately proved to be the most effective method for our analysis, we also had some success with the other marker systems tested. While RAPD markers and SCAR markers were useful in discriminating among species, their sometimes ambiguous inheritance (RAPD) or the time and expense necessary to derive them (SCAR) made them problematic for this study. Other marker systems, including ITS and SSR, although useful in other conifers for other purposes, were not useful for rapidly verifying interspecific hybrid hemlock progeny. Below, we describe the results of each of the marker systems we tested.

RAPD-PCR. In total, 75 10-nucleotide RAPD primers were tested. Although many of these primers yielded reproducible 


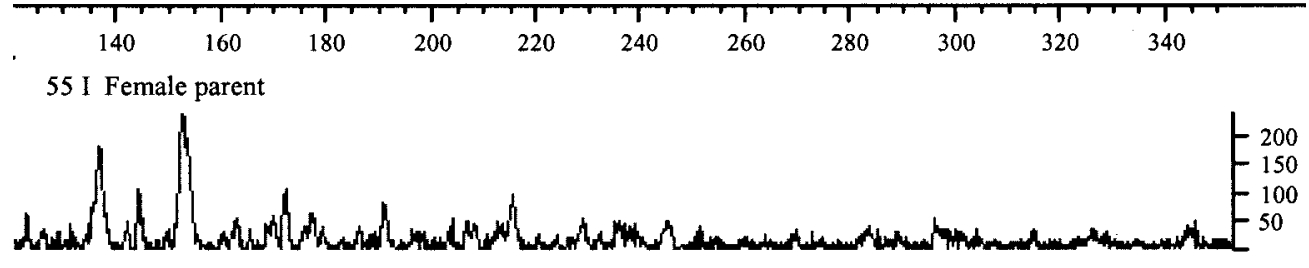

55K. Male parent

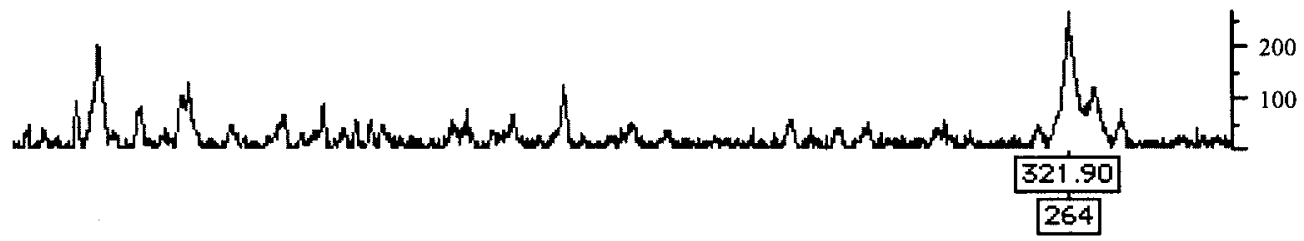

5594IK4 Progeny

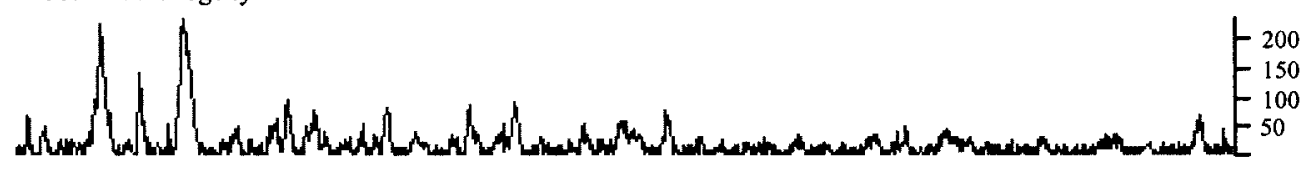

5594IK5 Progeny

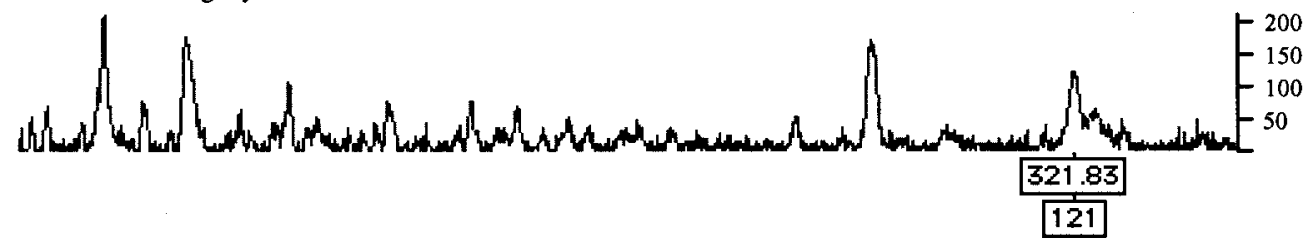

Fig. 1. Genotyper output of AFLP profiles of T. caroliniana (female), T. chinensis (male), and two progeny. The presence of the 322-bp marker in the male parent and the second progeny (5594IK5) is evidence that this individual is a hybrid.

polymorphic amplification profiles for the parental species with 3 to 10 amplification products per individual, RAPD markers were not useful in verifying hybrids. Faint paternal-specific bands in the putative progeny made absolute verification difficult, as did occasional non-parental bands in the progeny. Additionally, competition for primer binding site appeared to play a role in band intensity, as parental bands tended to be strong when there were few other amplification products and weaker when there were many other amplification products in the profile. Thus, although RAPD markers could potentially be useful in hemlock for assessing genetic diversity among individuals, their sometimes ambiguous inheritance made them unreliable for verifying hybrids.

STS AND SCAR PRIMERS. We tested three STS primer pairs reported previously, and 31 SCAR primer pairs derived in our lab specifically for this study. Although we were able to amplify control DNA from spruce using published STS primers, we were not able to amplify DNA from Tsuga. Thus, in contrast to the report by Perry and Bousquet (1998b), these primers were not useful in hemlock. Of the 31 SCAR primer pairs derived and tested, only 10 had the parental species specificity intended (Table 2). Most of the primers amplified DNA in all species, rather than only in the species from which the original unique RAPD band was observed. Such results are not unusual for SCAR markers (Paran and Michelmore, 1992) and are likely caused by a primer-template mismatch in the original 10-nucleotide RAPD primer region that is tolerated by the longer SCAR primer. Although a proportion of the SCAR primers were useful in differentiating between species and could therefore be used to verify putative hybrids, the usefulness of this technique in our study was limited by the efforts required to develop the markers.
ITS ANALYSIS. Primers Tcar425 and Tchin300 (Table 1) were based on sequence differences in the ITS region between $T$. caroliniana and T. chinensis. However, PCR amplification using either primer resulted in a product in all species tested. Restriction digestion of the purified ITS5-ITS2a region was also not effective in discriminating among species. Although restriction digestion of amplified ITS regions was somewhat effective in detecting hybridization in pines (Quijada et al., 1997), it was not useful in hemlock. Lack of sufficient diversity between species or multiple copies of the ITS region within the genome may have contributed to the lack of species specificity that we observed.

SSR ANALYSIS. We were hopeful that SSR primers developed for the western hemlock, $T$. heterophylla, would be useful for our species. Unfortunately, in our laboratory, the four primer pairs that we tested were either monomorphic or did not amplify a discrete product. Although the development of species-specific SSR primers has proven useful in many other plant species, the expense and expertise required to develop them was not available to us, so we did not pursue this option.

\section{Discussion}

Our method for screening parents and progeny for informative markers was influenced by the automated genetic analyzer and software. Because of the ease with which individual runs could be imported to the Genotyper software, we tended to choose markers useful for each specific cross, rather than search for markers that were unique to a particular species. Thus, for example, the set of $T$. chinensis markers used to verify hybrids with $T$. caroliniana might not be the same as the set used to verify hybrids with $T$. canadensis or even with other plants of $T$. caroliniana. While this method was the most convenient for organizing the large number of seedlings we examined, it limited our ability to follow the inheritance of a marker across a number of populations.

Choosing appropriate AFLP markers and testing seedlings that proved to be authentic hybrids was relatively straightforward; however, our results with some of the non-hybrid seedlings were more ambiguous. For example, the few putative $T$. chinensis $\mathrm{x} T$. canadensis seedlings inherited what appeared to be $T$. canadensisspecific markers (Table 1). However, because the majority of the $T$. canadensis-specific markers were not transmitted to the progeny, and testing of segregation ratios was not possible with so few individuals, we consider these few markers to be aberrant, and therefore could not classify these seedlings as authentic interspecific hybrids. These aberrant markers could be the result of DNA rearrangement during meiosis that resulted in comigrating but nonhomologous bands or possibly the result of contamination.

Although it was relatively easy to detect markers that differen- 
tiated among the Asian species or $T$. caroliniana, it was often much harder to find reliable markers that could be used to test seedlings derived from $T$. canadensis, and results from these crosses were ambiguous for some individual progeny. Although we are as yet uncertain of the reason for this discrepancy, we are testing the hypothesis that differences in levels of genetic variation exist between the Asian species and $T$. caroliniana and $T$. canadensis, possibly caused by population bottlenecks or inbreeding (Hawley et al., 2000; Zabinski, 1992). Paternal inheritance of chloroplast DNA, which has been reported in other conifers (Neale et al., 1986; Szmidt et al., 1987), is unlikely to have affected our ability to detect hybrid seedlings. Based on the seemingly simple inheritance of traits in a diploid genus with a relatively small number of chromosomes $(2 \mathrm{n}=2 \mathrm{X}=24$; Santamour, 1963; Sax and Sax, 1933), and the fact that apomixis is apparently rare (Asker and Jerling, 1992), the occasional ambiguous inheritance or elusive nature of informative markers for some crosses was somewhat unexpected.

Our work on interspecific compatibility between T.canadensis, $T$. caroliniana, and $T$. chinensis is consistent with phylogenetic studies in Tsuga published by Vining (1999). Based on sequence data from the ITS region, he concluded that despite its southeastern U.S. distribution, T. caroliniana is more closely related to the Asian species than it is to T. canadensis. In addition, studies by Wang et al. (1997) indicate substantial differences in chloroplast RFLP frequencies between $T$. canadensis and a population of $T$. caroliniana. It is interesting to note, however, that $T$. caroliniana is similar to T. canadensis in terms of its susceptibility to damage by the hemlock woolly adelgid.

Based on what we now realize about the difficulties in obtaining hybrids between $T$. canadensis and the Asian species, we plan to screen more of the $T$. canadensis $\times T$. caroliniana (and reciprocal) seedlings for authenticity, as these crosses could serve as bridges between $T$. canadensis and the Asian species. Although none of the six $T$. canadensis $\times T$. caroliniana seedlings, and only one of the ten $T$. caroliniana $\times T$. canadensis seedlings that we tested in this study proved to be hybrids, we are hopeful that examining more seedlings from these crosses will result in identification of additional hybrids of this promising interspecific combination.

Clearly, further studies are needed to clarify the relationships among the hemlock species and to overcome the apparent crossing barrier between $T$. canadensis and the Asian species. We plan to use the data compiled by AFLP analysis to compare genetic distances among the Asian and eastern North American species, to compare possible differences in outcrossing frequencies among the species, and to continue to verify interspecific hybrids that result from breeding efforts in Tsuga.

\section{Literature Cited}

Asker, S. and L. Jerling. 1992. Apomixis in plants. CRC Press, Boca Raton, Fla.

Barry, T., G. Colleran, M. Glennon, L.K. Dunican, and F. Gannon. 1991. The $16 \mathrm{~s} / 23 \mathrm{~s}$ ribosomal spacer region as a target for DNA probes to identify eubacteria. PCR Methods Appl. 1:51-56.

Bentz, S.E., L.G.H. Riedel, M.R. Pooler, and A.M. Townsend. 2002. Hybridization and self-compatibility in controlled pollinations of eastern North american and asian hemlock (Tsuga) species. J. Arboricult. (in press).

Gouli, S., B.L. Parker, and M. Skinner. 1997. Isolation of fungi associated with hemlock woolly adelgid (Homotera: Adelgidae). J. Invert. Pathol. 70:76-77.

Hawley, G.J,. D.H. DeHayes, and J.C. Brissette. 2000. Changes in the genetic diversity of eastern hemlock as a result of different forest management practices, p. 122. Proc. Symp. Sustainable Mgt. Hemlock Ecosystems in Eastern N. Amer., Durham, N.H., 22-24 June 1999. USDA Forest Serv. GTR-NE-267.

McClure, M.S. 1987. Biology and control of hemlock woolly adelgid. Conn. Agr. Expt. Sta. Bul. 851.

McClure, M.S. 1992. Hemlock woolly adelgid. Amer. Nurseryman 175(6):82-89.

McClure, M.S. 1995. Managing hemlock woolly adelgid in ornamental landscapes. Conn. Agr. Expt. Sta. Bul. 925.

McClure, M.S., S.M. Salom, and K.S. Shields. 1996. Hemlock woolly adelgid. USDA For. Serv. FHTET-96-35.

Montgomery, M.E. 1999. Woolly adelgids in the Southern Appalachians: Why they are harmful and prospects for control, p. 47-57. Proc. S. Appalachian Biol. Control Initiative Wkshp., 26-27 Sept. 1996. USDA For. Serv. FHTET-98-14.

Neale, D.B., N.C. Wheeler, and R.W. Allard. 1986. Paternal inheritance of chloroplast DNA in douglas-fir. Can. J. For. Res. 16:1152-1154.

Paran, I. and R.W. Michelmore. 1993. Development of reliable PCRbased markers linked to downy mildew resistance genes in lettuce. Theor. Appl. Genet. 85:985-993.

Perkin-Elmer Corporation. 1996. AFLP plant mapping. Protocol. Part 402083, rev. B. Applied Biosystems, Foster City, Calif.

Perry, D.J. and J. Bousquet. 1998a. Sequence-tagged-site (STS) markers of arbitrary genes: Development, characterization, and analysis of linkage in black spruce. Genetics 149:1089-1098.

Perry, D.J. and J. Bousquet. 1998b. Sequence-tagged-site (STS) markers of arbitrary genes: The utility of black spruce-derived STS primers in other conifers. Theor. Appl. Genet. 97:735-743.

Quijada, A., A. Liston, W. Robinson, and E. Alvarez-Buylla. 1997. The ribosomal ITS region as a marker to detect hybridization in pines. Mol. Ecol. 6:995-996.

Quimby, J.W. 1996. Value and importance of hemlock ecosystems in the eastern United States, p. 1-8. Proc. 1st Hemlock Woolly Adelgid Review, Charlottesville, Va. USDA Agr. For. Serv. FHTET 96-10.

Santamour, F.S. Jr. 1963. Chromosome number in Tsuga. Morris Arboretum Bul. 14:51.

Sax, K. and H.J. Sax. 1933. Chromosome number and morphology in the conifers. J. Arnold Arboretum 14: 356-375.

Souto, D.R. and K.S. Shields. 2000. Overview of hemlock health, p. 7680. Proc. Symp. Sustainable Mgt. Hemlock Ecosystems in Eastern N. Amer., Durham, N.H., 22-24 June 1999. USDA Forest Serv. GTRNE-267.

Swartley, J.C. 1984. The cultivated hemlocks. Timber Press, Portland, Ore.

Szmidt, A.E., T. Aldén, and J.E. Hällgren. 1987. Paternal inheritance of chloroplast DNA in Larix. Plant Mol. Biol. 9:59-64.

Taylor, R.J. 1993. Tsuga, p. 362-365. In: Flora of North America Editorial Committee (eds.). The flora of North America. vol. 2. Oxford Univ. Press, New York.

Vining, T. F. 1999. Molecular phylogenetics of Pinaceae (UMI microform 9926409). PhD diss., Univ. Maine, Orono.

Vos, P., R. Hogers, M. Bleeker, M. Reijans, T. van de Lee, M. Hornes, A Frijters, J. Pot, J. Peleman, M. Kuiper, and M.. Zabeau. 1995. AFLP: A new technique for DNA fingerprinting. Nucleic Acids Res. 23:44074414.

Wang, C., M.H. Perlin, R.R. van Stockum, Jr., C.H. Hamilton, and D.B. Wagner. 1997. Chloroplast DNA polymorphisms in Tsuga canadensis and Tsuga caroliniana. Can. J. For. Res. 27(9):1329-1335.

White, T.J., T. Bruns, S. Lee, and J. Taylor. 1990. Amplification and direct sequencing of fungal ribosomal RNA genes for phylogenetics, p. 315-322. In: M. Innis, D. Gelfand, J. Sninsky, and T. White (eds.). PCR protocols: A guide to methods and applications. Academic Press, San Diego, Calif.

Young, R.F., K.S. Shields, and G.P. Berlyn. 1995. Hemlock woolly adelgid (Homoptera: Adelgidae): Stylet bundle insertion and feeding sites. Ann. Entomol. Soc. Amer. 88:827-835.

Zabinski, C. 1992. Isozyme variation in eastern hemlock. Can. J. For. Res. 22:1838-1842. 